\title{
ANALISIS PEMUTUSAN HUBUNGAN KERJA AKIBAT ADANYA DEMOSI PADA PEKERJA PT JOHNSON HOME HYGIENE PRODUCTS (STUDI KASUS PUTUSAN MAHKAMAH AGUNG RI NOMOR 566 K/PDT.SUS- PHI/2014)
}

\author{
Monica \\ (Mahasiswi Program S1 Fakultas Hukum Universitas Tarumanagara) \\ (E-mail: monicbeliebs@yahoo.com)
}

\section{Stanislaus Atalim}

(Corresponding Author)

(Dosen Hukum Perjanjian Fakultas Hukum Universitas Tarumanagara, Meraih Sarjana Hukum dari Fakultas Hukum Universitas Indonesia, Magister Hukum dari Fakultas Hukum Universitas Indonesia, Doktor Hukum dari Fakultas Hukum Universitas Parahyangan Bandung)

(Email: st_atalim@yahoo.com)

\begin{abstract}
Demotion is the decline in the position of the labor/worker carried out by the company caused by the violation of the rules applicable within the company (indiscipline) which involves the decrease of authority, responsibility, status, facilities, even the salary earned from the company workers. This research is motivated by the implementation of termination of employment done by the company because the worker refuse to be demoted. The demotion made by the company is not caused by errors or violations committed by the worker / labor concerned but because of the restructuring department (the reason for efficiency). This study aims to analyze how the demotion validity that occurs in the worker of the company concerned and how the settlement process of termination of employment. This research was conducted by normative law research method that is by examining primary, secondary, and other non-legal material material supported by interview result. The results of the author shows that the demotion made by the company are not legitimate and not autonomously regulated in the company so that the termination of employment made by the company is an unfounded termination. This scientific study recommends the importance of the autonomous demotion regulation for the protection of workers.
\end{abstract}

Keywords: demotion, efficiency, Termination of Employment. 


\section{Pendahuluan}

\section{A. Latar Belakang}

Dalam masa Pembangunan Nasional, faktor ketenagakerjaan merupakan faktor yang teramat penting. Menurut Pasal 1 Ayat 1 UndangUndang Republik Indonesia Nomor 13 Tahun 2003 tentang Ketenagakerjaan, ketenagakerjaan adalah segala hal yang berhubungan dengan tenaga kerja pada waktu sebelum, selama, dan sesudah masa kerja. Faktor tenaga kerja sendiri merupakan faktor yang sangat dominan di dalam kehidupan suatu bangsa, karena ia merupakan faktor penentu bagi mati dan hidupnya suatu bangsa. Menurut Pasal 1 Ayat 2 Undang-Undang Republik Indonesia Nomor 13 Tahun 2003 tentang Ketenagakerjaan, tenaga kerja adalah setiap orang yang mampu melakukan pekerjaan guna menghasilkan barang dan/ atau jasa baik untuk memenuhi kebutuhan sendiri maupun untuk masyarakat. Pada umumnya tenaga kerja dibutuhkan dalam suatu perusahaan sebagai pekerja. Pekerja melakukan pekerjaan pada suatu perusahaan berdasarkan keahlian atau kemampuan yang dimiliki sehingga menentukan jabatan dari pekerja atau buruh. Setiap individu mempunyai keahliannya masing-masing yang dapat diandalkan untuk dijadikan pekerjaan atau profesi dalam memenuhi kebutuhan orang lain, sehingga dari profesinya tersebut memperoleh pendapatan berupa nilai jual yang secara ekonomis dapat menafkahi dirinya sendiri dan keluarganya.

Manajemen sumber daya manusia atau manajemen secara umum sering dihadapkan pada keputusan yang akan diberikan pada para pekerja atau buruh. Dalam mengelola sumber daya manusia, adakalanya seorang manajer sumber daya manusia harus melakukan pemindahan pekerja atau buruh baik itu berupa promosi, mutasi, maupun demosi. Semua itu pada umumnya didasarkan pada proses penilaian kinerja atau penyesuaian pada badan organisasi untuk mendapatkan susunan yang terbaik pada tiap-tiap 
sumber daya manusia yang tersedia agar perusahaan dapat berjalan dan memberikan kinerja yang baik. Penilaian prestasi kerja adalah proses organisasi perusahaan dalam menilai kinerja pekerja atau buruh yang dilakukan dengan tujuan untuk memberikan feedback kepada pekerja atau buruh dalam upaya memperbaiki kinerja guna pencapaian peningkatan produktivitas organisasi perusahaan, dengan cara melaksanakan berbagai program kebijaksanaan terhadap pekerja atau buruh seperti pendidikan dan pelatihan, pemberian promosi dan penjatuhan sanksi demosi. ${ }^{1}$

Dalam pelaksanaannya, demosi dilakukan bagi pekerja atau buruh yang dinilai manajemen perusahaan memiliki prestasi kerja yang rendah. Demosi juga merupakan sejenis sanksi atau hukuman bagi pekerja atau buruh yang melakukan kesalahan atau pelanggaran terhadap peraturan perusahaan (indisipliner). Pengertian demosi adalah suatu perpindahan dalam suatu organisasi dari satu posisi ke posisi lainnya yang melibatkan penurunan kewenangan, tanggung jawab, status, fasilitas, bahkan gaji yang diperoleh oleh pekerja/buruh tersebut dari perusahaan. ${ }^{2}$

Penjatuhan sanksi demosi penting dilakukan secara tegas oleh manajemen perusahaan, agar perusahaan tidak mengalami kerugian kerugian yang lebih besar dan juga pekerja atau buruh lainnya tidak ikut tertular berprestasi rendah dalam organisasi perusahaan tersebut. Sanksi demosi yang dijatuhkan manajemen perusahaan terhadap pekerja atau buruh yang berprestasi rendah merupakan suatu therapy bagi pekerja atau buruh lainnya agar mampu memperbaiki diri dan terus menerus belajar dalam meningkatkan kualitas diri. Dengan demikian pekerja atau buruh yang memiliki prestasi kerja yang rendah akan berupaya semaksimal mungkin

1 Marihot Tua Effendi Hariandja, Manajemen Sumber Daya Manusia, Pengadaan, Pengembangan, Pengkompensasian dan Pengikatan Produktivitas Karyawan, (Jakarta: Gramedia, 2002), hal. 26.

${ }^{2}$ Ibid, hal.48. 
untuk memperbaiki kualitas diri baik dari segi keterampilan di dalam menyelesaikan maupun dari segi wawasan pengetahuan yang berhubungan dengan bidang pekerjaan yang ditanganinya.

Dalam mencapai tujuannya, perusahaan juga sangat dipengaruhi oleh tenaga kerjanya. Dalam proses tersebut ada beberapa hal yang harus diperhatikan salah satunya adalah pemutusan hubungan kerja. Pemutusan hubungan kerja (yang selanjutnya disebut dengan PHK) adalah pengakhiran hubungan kerja antara pengusaha dengan pekerja yang terjadi karena berbagai sebab. ${ }^{3}$ Soal pemutusan atau pengakhiran hubungan kerja adalah suatu masalah yang besar akibatnya bagi pekerja atau buruh, karena dengan berakhirnya hubungan kerja, bagi pekerja atau buruh berarti kehilangan mata pencaharian, sehingga pekerja tersebut tidak dapat lagi memenuhi kebutuhannya secara maksimal untuk pekerja dan keluarganya. PHK sejatinya merupakan "awal kesengsaraan karena sejak saat itu penderitaan akan menimpa bagi pekerja itu sendiri maupun keluarganya dengan hilangnya penghasilan". Sehingga untuk menjamin kepastian dan ketentraman hidup para pekerja atau buruh, seharusnya tidak ada pemutusan hubungan kerja. Jika setiap orang berhak atas pekerjaan, orang itu setelah mendapat pekerjaan harus berhak pula untuk terus bekerja, artinya tidak diputuskan hubungan kerjanya pada esok harinya setelah ia mendapatkan pekerjaan. Oleh karena itu seharusnya tidak ada pemberhentian pekerja atau buruh sama sekali. ${ }^{5}$

Dalam perkembangannya, ketentuan pemberhentian pekerja atau buruh berkembang menjadi tidak hanya terbatas pada pemberhentian yang

${ }^{3}$ Lalu Husni, Pengantar Hukum Ketenagakerjaan Indonesia, (Jakarta: PT Raja Grafindo Persada, 2000), hal. 133. hal. 44 .

${ }^{4}$ F.X. Djumialdji, Perjanjian Kerja Edisi Revisi, Cetakan ke-4, (Jakarta: Sinar Grafika, 2010),

${ }^{5}$ Imam Soepomo, Hukum Perburuhan Bidang Hubungan Kerja, cetakan ke-8, (Jakarta: Djambatan, 1994), hal. 145. 
mengakibatkan penderitaan pekerja atau buruh yang telah atau akan diberhentikan, tetapi juga membatasi atau menyerang kebebasan pengusaha untuk melakukan pemberhentian, dan menetapkan suatu asas yang lebih umum, yaitu bahwa tiap pemberhentian pengusaha harus didasarkan alasan inti yang membenarkan pemberhentian itu. Lazimnya bahwa seorang pekerja atau buruh yang diberhentikan berhak untuk menentang pemberhentiannya itu tidak beralasan, melalui suatu cara pengaduan dan jika perlu melalui suatu pengadilan dan atau suatu badan arbitrase atau badan lainnya yang tidak memihak ataupun suatu badan kerja sama yang berwenang memeriksa dan mengambil putusan terhadap soal yang dijadikan alasan pemberhentian tersebut. ${ }^{6}$

Pemutusan hubungan kerja dapat dibagi dalam 4 (empat) golongan, yaitu Pertama, pemutusan hubungan kerja oleh majikan atau pengusaha. Kedua, pemutusan hubungan kerja oleh buruh atau pekerja. Ketiga, hubungan kerja putus demi hukum. Keempat, pemutusan hubungan kerja oleh pengadilan. ${ }^{7}$

Terkait dalam pembahasan di atas, pada kasus pemutusan hubungan kerja yang dilakukan oleh PT Johnson Home Hygiene Products terhadap salah satu pekerjanya yaitu Zairianti, yang ingin penulis bahas yaitu pemutusan hubungan kerja yang disebabkan karena adanya demosi. Di dalam Putusan Mahkamah Agung No. 566K/Pdt.Sus-PHI/2014 tersebut akan dianalisis mengenai perusahaan yang melakukan restrukturisasi departemen sehingga menimbulkan demosi pada salah satu pekerja atau buruh yang menjabat sebagai Logistic Manager menjadi Logistic Cost Controller. Hal ini mengakibatkan pekerja atau buruh menjadi turun jabatan menjadi 2 (dua) level di bawah. Oleh karena pekerja atau buruh tidak menyetujui

\footnotetext{
${ }^{6}$ A. Ridwan Halim dan Sri Subiandini Gultom, Sari Hukum Perburuhan Aktual, cetakan 1, (Jakarta: Djambatan, 1984), hal. 145.

7 Sendjun H. Manulang, Pokok-Pokok Hukum Ketenagakerjaan Indonesia, cetakan ke-2, (Jakarta:Rineka Cipta, 1995), hal. 120
} 
dilakukannya demosi, maka perusahaan menawarkan PHK kepada pekerja atau buruh tersebut. Dimana pada Putusan Pengadilan Hubungan Industrial Nomor 238/PHI.G/2013/PN.JKT.PST, PHI memutuskan bahwa terjadinya pemutusan hubungan kerja antara pihak perusahaan dan pekerja. Begitu juga pada Putusan Mahkamah Agung No. 566K/Pdt.Sus-PHI/2014 yang menguatkan Putusan Pengadilan Hubungan Industrial yang memutuskan terjadinya pemutusan hubungan kerja antara perusahaan dan pekerja serta menambahkan upah skorsing bagi pekerja. Hal ini menimbulkan pertanyaan terhadap tindakan tersebut apakah mempunyai legalitas hukum yang dapat dipertanggungjawabkan.

Berangkat dari paparan di atas, maka penulis tertarik untuk melakukan kajian ilmiah yang lebih lanjut dan mendalam tentang Analisis Pemutusan Hubungan Kerja Akibat Adanya Demosi Pada Pekerja PT Johnson Home Hygiene Products (Studi Kasus Putusan Mahkamah Agung Nomor 566 K/Pdt.Sus-PHI/2014).

\section{B. Perumusan Masalah}

Berdasarkan uraian latar belakang di atas, maka penulis mengangkat permasalahan:

1. Bagaimana keabsahan demosi yang terjadi pada pekerja atau buruh di PT Johnson Home Hygiene Products?

2. Bagaimana perlindungan hukum bagi pekerja atau buruh yang mengalami PHK karena menolak demosi di PT Johnson Home Hygiene Products?

\section{Pembahasan}

\section{A. Keabsahan Demosi yang Terjadi Pada Pekerja atau Buruh di PT} Johnson Home Hygiene Products

Menurut Manullang, demosi terjadi dalam suatu perusahaan terutama karena pengaruh negatifnya terhadap moral karyawan yang bersangkutan 
dan dapat mempengaruhi prestasi dan moral karyawan lainnya di perusahaan tersebut. ${ }^{8}$ Sebagai lawan dari promosi, demosi dimaksud ialah penugasan pekerja/buruh memangku jabatan-jabatan yang statusnya, tanggung jawab dan gajinya lebih kecil dari jabatan semula. ${ }^{9}$ Umumnya demosi dilakukan karena pekerja/buruh yang bersangkutan telah melakukan pelanggaran atas peraturan perusahaan, namun lebih banyak disebabkan oleh ketidakmampuan pekerja/buruh dalam menjalankan fungsi dari jabatan yang menjadi tanggung jawabnya.

Demosi merupakan perpindahan pekerja/buruh dalam bentuk penurunan jabatan. Demosi dilakukan atas kewenangan dari perusahaan, yang berdasarkan alasan-alasan tertentu, seperti penilaian negatif oleh atasan karena prestasi kerja yang tidak/kurang memuaskan, pekerja/buruh yang disfungsional misalkan kemangkiran yang tinggi. Pada umumnya, alasan utama yang dijadikan dasar untuk melakukan demosi adalah pekerja melakukan pelanggaran atau kesalahan atau tindakan yang merugikan perusahaan. Pertimbangan dalam hal penempatan pekerja/buruh yang di demosi harus dengan kompetensi, prestasi kerja, dan jenjang pangkat yang ditetapkan untuk jabatan itu.

Kebutuhan untuk dilakukannya demosi pekerja/buruh dapat disebabkan oleh, pertama berdasarkan penilaian yang obyektif adil dan transparan, pekerja/buruh tersebut dinilai tidak mampu memegang jabatan tersebut, dan kedua melakukan pelanggaran disiplin kerja yang dilakukan berulang kali yang berkaitan dengan jabatannya, walaupun tidak terjadi kecelakaan, menyalahgunakan jabatan untuk keperluan pribadi ketidakdisiplinan waktu kerja, membuang-buang waktu kerja sehingga menimbulkan proses kerja

\footnotetext{
${ }^{8}$ Noor Aini Pratitha A.L dan Yasmin Chairunisa Muchtar, "Pengaruh Penerapan Promosi Dan Demosi Terhadap Prestasi Kerja Karyawan Pada Master Kredit Cabang Medan”, Jurnal USU. Volume 1, Nomor 1 Tahun 2013, hal. 13.

${ }^{9}$ M. Manullang dan Marihot Amh Manullang, Manajemen Personalia, (Yogyakarta: Gadjah Mada University Press, 2011), hal. 153.
} 
yang tidak efisien, dan menggunakan waktu kerja diluar kepentingan perusahaan. Prosedur dilakukannya demosi, yakni sebagaimana kebijakan perusahaan tentu harus dikomunikasikan, disosialisasikan kepada pekerja atau buruh. Ketika pekerja atau buruh tidak menerima kebijakan perusahaan dimaksud, tentu hal tersebut menjadi agenda dari perselisihan. Ketika sudah menjadi agenda dari perselisihan maka hak dan kewajiban masing-masing pihak tentu harus terus berjalan sebagaimana diatur dalam UU Ketenagakerjaan. Jadi hak dan kewajiban masing-masing pihak terus berjalan sampai adanya putusan yang mempunyai kekuatan yang mengikat untuk menyatakan apakah demosi itu sah atau tidak, apakah sudah sesuai dengan ketentuan atau mungkin demosi itu tidak masuk akal.

Mengenai demosi tidak diberikan pengaturannya dalam UndangUndang Nomor 13 Tahun 2003 tentang Ketenagakerjaan, yang selanjutnya disebut UU Ketenagakerjaan maupun peraturan perundang-undangan lain terkait dengan ketenagakerjaan. Dengan demikian, pengaturan demosi ini dapat diatur sendiri di dalam perjanjian kerja, peraturan perusahaan atau perjanjian kerja bersama. Sehingga hal-hal yang terkait dengan pengenaan disiplin terhadap pekerja atau buruh yang melakukan pelanggaran dan merugikan perusahaan sebenarnya lebih diserahkan kepada pihak pengusaha dan pekerja atau buruh untuk disepakati bersama dalam bentuk Perjanjian Kerja atau Peraturan Perusahaan atau Perjanjian Kerja Bersama.

Sistem demosi, yang biasanya identik dengan proses promosi-demosi, merupakan bagian dari program manajemen sumber daya manusia dalam hal reward dan punishment atas kinerja pekerja/buruh. Program ini bertujuan untuk mendorong produktifitas sekaligus mengasah kemampuan dari setiap pekerja/buruh. Mengingat pentingnya program ini, maka ketentuan demosi harus diterapkan tanpa harus melanggar peraturan perundang-undangan yang berlaku, terutama Undang-Undang Nomor 13 Tahun 2003 tentang Ketenagakerjaan. Menerapkan ketentuan demosi yang tidak diatur dalam 
peraturan perusahaan saja berpotensi melanggar UU Ketenagakerjaan, terlebih bila tidak diatur sama sekali. Tentunya hal ini memiliki konsekuensi yang dapat mengakibatkan demosi batal demi hukum dan hubungan kerja kembali pada ketentuan sesuai dengan perjanjian kerja semula. Ketentuan demosi dapat diterapkan tanpa harus melanggar UU Ketenagakerjaan dengan menuangkan ketentuan tersebut dalam Perjanjian Kerja, Peraturan Perusahaan dan/atau Perjanjian Kerja Bersama. Bila demosi hanya diatur dalam Peraturan Perusahaan, maka ketentuan tersebut harus dijelaskan kepada pekerja/buruh sebelum menandatangani perjanjian kerja.

Demosi merupakan salah satu bagian dari pengembangan pekerja atau buruh secara formal untuk menciptakan kompetisi di antara sesama pekerja atau buruh guna memacu prestasi kerja para pekerja atau buruh. ${ }^{10}$ Tujuan dilakukannya demosi terhadap pekerja/buruh yang bersangkutan adalah untuk pembinaan dan pembelajaran bagi pekerja. Apabila manajemen menganggap masih adanya harapan bagi pekerja atau buruh tersebut untuk memperbaiki diri maka tindakan demosi diberikan dengan sanksi yang mendidik pekerja atau buruh tersebut ke arah yang lebih baik. Disamping tujuan pembelajaran, penjatuhan sanksi demosi juga dimaksudkan untuk menghindari kerugian perusahaan yang lebih besar karena telah salah menempatkan pekerja atau buruh di posisinya. Demosi seringkali merubah motivasi pekerja/buruh yang bersangkutan dan juga mempengaruhi pekerja/buruh lain. Oleh karena itu, demosi harus dilakukan melalui tahapantahapan yang tepat. Penurunan jabatan pekerja/buruh dalam perusahaan jarang terjadi, terutama karena pengaruh negatifnya terhadap moral pekerja/buruh.

Sumber daya manusia di perusahaan perlu dikelola secara profesional agar terwujud keseimbangan antara kebutuhan pekerja/buruh dengan

\footnotetext{
${ }^{10}$ Suratman, Manajemen Sumber Daya Manusia, (Jakarta: Raja Grafindo, 2006), hal. 26.
} 
tuntutan dan kemampuan organisasi perusahan. Keseimbangan tersebut merupakan kunci utama perusahaan agar dapat berkembang secara produktif dan wajar. ${ }^{11}$ Dapat disimpulkan demosi adalah tindakan yang tepat bagi pekerja/buruh apabila dalam proses kerjanya tidak dapat menyelesaikan tuntutan kerja atau prestasi kerja.

Pada kasus pemutusan hubungan kerja terhadap pekerja di PT Johnson Home Hygiene Products, justru bertentangan dengan alasan utama yang harusnya menjadi dasar untuk melakukan demosi. Tergugat yang pada jabatannya sebagai Logistic Manager telah berusaha bekerja berdasarkan fungsi jabatannya dengan baik, serta Tergugat telah memberikan keuntungan kepada perusahaan dengan mengupayakan proyek Cost Saving - Carrefour Delivery DC Instead of Store. Akan tetapi, ketika Tergugat menolak untuk di PHK karena alasan restrukturisasi departemen yang merupakan bentuk dari efisiensi, kemudian Tergugat malah didemosikan dari jabatan Logistic Manager menjadi Logistic Cost Controller. Dimana diketahui bahwa Logistic Cost Controller merupakan 2 (dua) level lebih rendah dari jabatan sebelumnya. Dasar Penggugat untuk melakukan demosi kepada Tergugat, yaitu dikarenakan Restrukturisasi Departemen yang merupakan bentuk dari efisiensi. Menurut Sehat Damanik, S.H., M.H., efisiensi dan demosi merupakan dua hal yang berbeda dan tidak dapat dikaitkan. Alasan efisiensi sendiri tidak dapat dijadikan suatu dasar bagi perusahaan untuk melakukan demosi pada pekerjanya. Apabila perusahaan ingin melakukan efisiensi dengan memindahkan jabatan pekerja, maka jabatan yang diberikan harus sepadan dengan jabatan pekerja yang terdahulu. Artinya sesuai dengan kompetensi, kemampuan, dan keahlian dari pekerja. Efisiensi yang dilakukan oleh perusahan juga terkesan tidak valid melihat bahwa pihak perusahaan tidak memenuhi syarat dari ketentuan Pasal 164 Ayat 2 UU

${ }^{11}$ A.A. Anwar Prabu Mangkunegara, Manajemen Sumber Daya Manusia Perusahaan, (Bandung: Remaja Rosdakarya, 2002), hal. 33. 
Ketenagakerjaan yaitu kerugian perusahaan harus dibuktikan dengan laporan keuangan 2 (dua) tahun terakhir yang telah diaudit oleh akuntan publik. Oleh karena itu tidak relevan apabila alasan efisiensi dijadikan dasar untuk melakukan demosi pada pekerja, terlebih juga pekerja/buruh tidak melakukan kesalahan atau pelanggaran yang merugikan pihak perusahaan. Jika dilihat dari sisi manajemen, meskipun Tergugat harus menerima jabatan baru, maka seharusnya Tergugat menerima jabatan yang minimal selevel dengan jabatan sebelumnya sehinngga upah Tergugat tetap (tidak berkurang dari hak-hak yang diperoleh sebelumnya). Dengan demikian patut dikatakan bahwa demosi yang terjadi merupakan demosi yang tidak beralasan.

Mengenai demosi itu sendiri hanya diatur secara umum dan tidak diatur secara khusus dalam UU No. 13 Tahun 2003 tentang Ketenagakerjaan, sehingga sebaiknya diatur secara otonom oleh perusahaan yaitu pada Peraturan Perusahaan, Perjanjian Kerja, atau Perjanjian Kerja Bersama. Namun demikian, perusahaan tempat Tergugat bekerja tidak mengatur mengenai demosi. Pada Perjanjian Kerja Bersama hanya mengatur mengenai mutasi dan promosi, sebagaimana tertuang pada Pasal 10 dan Pasal 11 PKB antara PT Johnson Home Hygiene Products dengan serikat pekerja PT Johnson Home Hygiene Products Periode 2013-2015. Oleh karena berdasarkan hukum otonom perusahaan, tindakan demosi tidak semestinya dilakukan.

Berkaitan dengan hal PT Johnson Home Hygiene Products memberikan jabatan baru kepada pekerja Zairianti sebagai pengganti dihapusnya posisi jabatan pekerja yang merupakan tujuan dari restrukturisasi departemen, semestinya dalam hal pemberian jabatan baru, pekerja diberikan jabatan baru yang memiliki posisi jabatan yang paling tidak setara dengan jabatan sebelumnya. Mutasi atau penempatan pekerja ke tempat lain harus memperhatikan berlakunya Pasal 32 UU Ketenagakerjaan, yaitu pertama penempatan tenaga kerja dilaksanakan berdasarkan asas terbuka, bebas, 
objektif, serta adil dan setara tanpa diskriminasi. Kedua, penempatan tenaga kerja diarahkan untuk menempatkan tenaga kerja pada jabatan yang tepat sesuai dengan keahlian, keterampilan, bakat, minat, dan kemampuan dengan memperhatikan harkat, martabat, hak asasi, dan perlindungan hukum. Ketiga, penempatan tenaga kerja dilaksanakan dengan memperhatikan pemerataan kesempatan kerja dan penyediaan tenaga kerja sesuai dengan kebutuhan program nasional dan daerah. Akan tetapi pada putusan ini, demosi yang dilakukan oleh PT Johnson Home Hygiene Products justru bertentangan dengan pasal tersebut. Mengingat pada pertemuan bipartit, PT Johnson Home Hygiene Products menyatakan bahwa demosi yang terjadi bersifat rahasia, serta pekerja Zairianti hanya diberikan pilihan untuk memilih di PHK atau menerima demosi tersebut. Sehingga pada akhirnya pekerja yang menolak untuk didemosikan harus menerima pemutusan hubungan kerja.

Menurut Dr. Andari Yurikosari, S.H., M.H., pemutusan hubungan kerja yang dilakukan oleh PT Johnson Home Hygiene Products sendiri tidak tepat. Masalah mengenai pemutusan hubungan kerja (PHK) selalu menarik untuk dikaji dan ditelaah lebih mendalam karena sebagian besar pekerja/buruh selalu menjadi pihak yang lemah apabila dihadapkan pada pemberi kerja yang merupakan pihak yang memiliki kekuatan. Sebagai pihak yang selalu dianggap lemah, tidak jarang para pekerja/buruh selalu mengalami ketidakadilan apabila berhubungan dengan kepentingan perusahaan. Menurut Pasal 1 Ayat (25) Undang-Undang Nomor 13 Tahun 2003 tentang Ketenagakerjaan, pemutusan hubungan kerja adalah pengakhiran hubungan kerja karena suatu hal tertentu yang mengakibatkan berakhirnya hak dan kewajiban antara pekerja/buruh dan pengusaha. Hal ini bisa terjadi karena ketidakcocokan pengusaha pada pekerja atau faktor-faktor lain yang terkait 
dengan perkembangan perusahaan. ${ }^{12}$ Seperti diketahui bahwa perusahaan menggugat ke PHI dengan gugatan PHK menggunakan alasan kesalahan/pelanggaran berat yang dilakukan pekerja. Sesuai dengan UU Ketenagakerjaan, pengusaha dapat melakukan PHK terhadap pekerja/buruh dengan alasan pekerja/buruh melakukan kesalahan berat seperti melakukan penipuan, pencurian atau penggelapan barang dan/atau uang milik perusahaan. Kemudian memberikan keterangan palsu atau yang dipalsukan sehingga merugikan perusahaan. Mabuk, meminum minuman keras yang memabukkan, memakai dan/atau mengedarkan narkotika, psikotropika, dan aditif lainnya di lingkungan kerja. Tidak hanya itu, melakukan perbuatan asusila atau perjudian di lingkungan kerja. Menyerang, menganiaya, mengancam atau mengintimidasi teman sekerja atau pengusaha di lingkungan kerja. Membujuk teman sekerja atau pengusaha untuk melakukan perbuatan yang bertentangan dengan peraturan perundangundangan. Dengan ceroboh atau sengaja merusak atau membiarkan dalam keadaan bahaya milik perusahaan yang menimbulkan kerugian bagi perusahaan. Dengan ceroboh atau sengaja membiarkan teman sekerja atau pengusaha dalam keadaan bahaya di tempat kerja. Membongkar atau membocorkan rahasia perusahaan yang seharusnya dirahasiakan. Serta melakukan perbuatan lainnya di lingkungan perusahaan yang diancam pidana lima tahun atau lebih.

Kesalahan/pelanggaran berat yang dituduhkan oleh perusahaan disebabkan oleh tindakan pekerja yang mengirimkan e-mail kepada 37 (tiga puluh tujuh) temannya mengenai pemutusan hubungan kerja dan tawaran demosi yang diberikan oleh pihak perusahaan. Namun pada kenyataannya pekerja sendiri tidak terbukti melakukan kesalahan/pelanggaran berat

${ }^{12}$ Soedarjadi, Hukum Ketenagakerjaan di Indonesia, (Yogyakarta: Pustaka Yustisia, 2008), hal. 103. 
sehingga PHK yang dilakukan terkesan bentuk dari akal-akalan perusahaan yang bertujuan agar pekerja dapat di putus hubungan kerjanya dengan pesangon yang lebih kecil atau bahkan tanpa pesangon. Jika memang ternyata perusahaan ingin mem-PHK pekerja dengan alasan restrukturisasi departemen yang merupakan bentuk dari efisiensi, maka seharusnya perusahaan dapat menawarkan bentuk kompensasi seperti pesangon dan sebagainya dengan jumlah yang lebih besar dari apa yang ditetapkan oleh undang-undang.

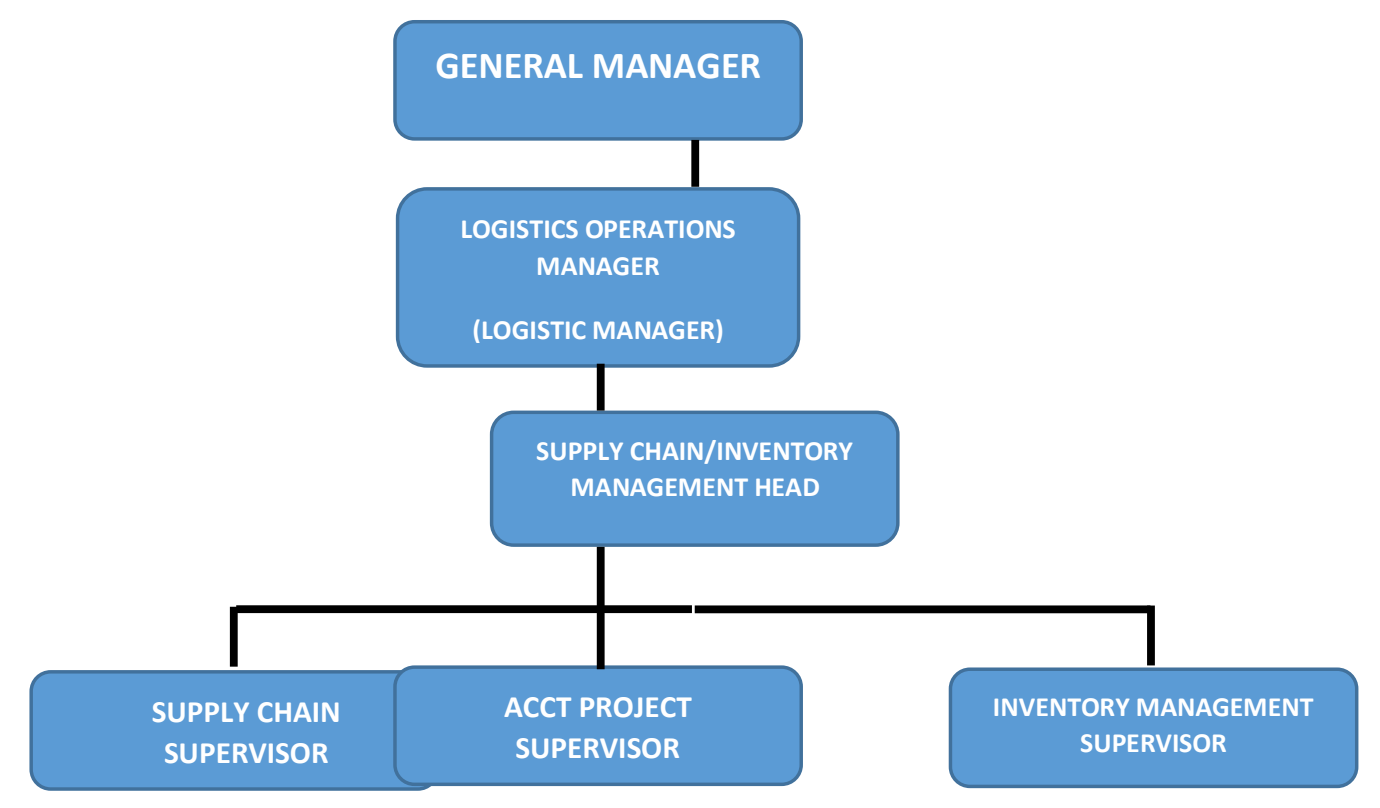


Berdasarkan hasil wawancara dengan Dr. Andari Yurikosari, S.H., M.H. dan melihat bagan struktur organisasi perusahaan pada umumnya seperti yang tercantum, diketahui bahwa jabatan Logistic Manager/Logistic Operations Manager berada tepat 1 unit di bawah General Manager. Hal ini membuktikan bahwa jabatan Logistic Manager merupakan salah satu posisi jabatan Manager tertinggi pada divisi logistik. Dengan posisi Logistic Manager yang sudah ditempati oleh pekerja dalam masa kerja lebih dari 10 (sepuluh) tahun, dapat dikatakan bahwa demosi yang dilakukan merupakan demosi yang akal-akalan yang bertujuan agar perusahaan dapat mengangkat orang baru ke dalam struktur organisasi perusahaan. Dengan mengangkat orang baru ke dalam struktur organisasi perusahaan, maka gaji yang diberikan akan lebih kecil dibandingkan dengan Logistic Manager yang sudah dipekerjakan selama 10 (sepuluh) tahun. Tercantum pada Putusan Mahkamah Agung No. 566 K.Pdt.Sus-PHI/2014, selain mengangkat orang baru, perusahaan kemudian juga menurunkan jabatan pekerja menjadi Logistic Cost Controller sehingga demosi yang dilakukan merupakan suatu hal yang disengaja agar pekerja tidak mungkin lagi semerta-merta menolak pemutusan hubungan kerja yang ditawarkan kepadanya. Hal ini terkesan trik yang dilakukan perusahaan agar dapat melakukan PHK terhadap pekerjanya karena kepentingan perusahaan semata dan bukan suatu alasan dari adanya efisiensi.

Menurut J. Erikson Sinambela, S.H., M.H., demosi yang dilakukan terhadap pekerja Zairianti bertentangan dengan suatu asas yang menyebutkan bahwa apa yang biasa diberikan tidak boleh dikurangi. Mengingat juga apabila pengaturan demosi tidak diatur secara otonom oleh pengusaha, maka jika terjadi demosi terdapat larangan yang timbul 
akibatnya seperti yang diatur dalam Pasal 151 UU Ketenagakerjaan yaitu pengusaha, pekerja/buruh, maupun pemerintah, dengan segala upaya harus mengusahakan agar tidak terjadi pemutusan hubungan kerja.

Dapat dikatakan bahwa keabsahan demosi yang terjadi pada pekerja/buruh di PT Johnson Home Hygiene Products tidak dapat dibenarkan karena tidak memenuhi syarat-syarat untuk dilakukannya demosi. Pertama, demosi yang dilakukan bukan karena adanya kesalahan atau pelanggaran yang dilakukan oleh pekerja/buruh. Kedua, penolakan PHK karena adanya alasan efisiensi tidak dapat dijadikan alasan bagi perusahaan untuk mendemosikan pekerjanya. Terlebih alasan PHK karena adanya efisiensi juga harus memenuhi ketentuan Pasal 164 ayat 2 UndangUndang Nomor 13 Tahun 2013 tentang Ketenagakerjaan. Ketiga, demosi tidak diatur secara khusus dalam Peraturan Perusahaan, Perjanjian Kerja, atau Perjanjian Kerja Bersama. Sehingga dapat dikatakan bahwa demosi yang terjadi pada pekerja di PT Johnson Home Hygiene Products merupakan demosi yang tidak sah karena merupakan demosi yang tidak beralasan dan bersifat inkonstitusional.

\section{B. Perlindungan Hukum Bagi Pekerja atau Buruh yang Mengalami PHK} Karena Menolak Demosi di PT Johnson Home Hygiene Products

Perlindungan hukum adalah perbuatan dalam hal melindungi peraturan; keseluruhan peraturan guna melindungi masyarakat agar mencapai tujuantujuan negara. ${ }^{13}$ Menurut Setiono, perlindungan hukum adalah tindakan atau upaya untuk melindungi masyarakat dari perbuatan sewenang-wenang oleh penguasa yang tidak sesuai dengan aturan hukum, untuk mewujudkan ketertiban dan ketentraman sehingga memungkinkan manusia untuk menikmati martabatnya sebagai manusia. Menurut Satijipto Raharjo,

\footnotetext{
${ }^{13}$ Subekti, Hukum Perdata, (Bandung: Intemasa,2003), hal.21.
} 
perlindungan hukum adalah memberikan pengayoman terhadap hak asasi manusia (HAM) yang dirugikan orang lain dan perlindungan itu di berikan kepada masyarakat agar dapat menikmati semua hak-hak yang diberikan oleh hukum. Hukum dapat difungsikan untuk mewujudkan perlindungan yang sifatnya tidak sekedar adaptif dan fleksibel, melainkan juga prediktif dan antisipatif. Hukum dibutuhkan untuk mereka yang lemah dan belum kuat secara sosial, ekonomi dan politik untuk memperoleh keadilan sosial. ${ }^{14}$

Philipus M. Hadjon berpendapat bahwa ada dua bentuk perlindungan hukum bagi rakyat, yaitu perlindungan hukum preventif dan perlindungan hukum represif. ${ }^{15}$ Perlindungan hukum preventif, yakni bentuk perlindungan hukum di mana subjek hukum diberi kesempatan untuk mengajukan keberatan atau pendapat sebelum suatu keputusan pemerintah mendapat bentuk yang definitif. Tujuannya adalah mencegah terjadinya sengketa. Perlindungan hukum preventif sangat besar artinya bagi tindak pemerintahan yang didasarkan pada kebebasan bertindak karena dengan adanya perlindungan hukum yang preventif pemerintah terdorong untuk bersifat hati-hati dalam mengambil keputusan yang didasarkan pada diskresi. Di Indonesia belum ada pengaturan khusus mengenai perlindungan hukum preventif. Perlindungan hukum represif, yakni bentuk perlindungan hukum di mana lebih ditujukan dalam penyelesaian sengketa. Penanganan perlindungan hukum oleh Pengadilan Umum dan Pengadilan Administrasi di Indonesia termasuk kategori perlindungan hukum ini. Prinsip perlindungan hukum terhadap tindakan pemerintah bertumpu dan bersumber dari konsep tentang pengakuan dan perlindungan terhadap hak-hak asasi manusia karena menurut sejarah dari barat, lahirnya konsep-konsep tentang pengakuan dan perlindungan terhadap hak-hak asasi manusia diarahkan kepada pembatasan-

\footnotetext{
${ }^{14}$ Satjipto Raharjo, Ilmu Hukum, (Bandung: Citra Aditya Bakti, 2000), hal.53.

${ }^{15}$ Philipus M. Hadjon. Perlindungan Hukum Bagi Rakyat Indonesia, (Surabaya: Peradaban, 2007), hal. 2.
} 
pembatasan dan peletakan kewajiban masyarakat dan pemerintah. Prinsip kedua yang mendasari perlindungan hukum terhadap tindak pemerintahan adalah prinsip negara hukum. Dikaitkan dengan pengakuan dan perlindungan terhadap hak-hak asasi manusia, pengakuan dan perlindungan terhadap hak-hak asasi manusia mendapat tempat utama dan dapat dikaitkan dengan tujuan dari negara hukum. ${ }^{16}$

Dalam melaksanakan pembangunan nasional, peran serta pekerja/buruh semakin meningkat dan seiring dengan itu perlindungan pekerja/buruh harus semakin ditingkatkan baik mengenai upah, kesejahteraan dan harkatnya sebagai manusia (to make more human) ${ }^{17}$ Terlebih terhadap pekerja/buruh yang mengalami pemutusan hubungan kerja khususnya dalam kasus ini dikarenakan menolak terjadinya demosi. Sesuai dengan pernyataan Satijipto Raharjo mengenai perlindungan hukum khususnya bagi pekerja/buruh yang di PHK, perlindungan hukum seharusnya merupakan bentuk pengayoman terhadap hak asasi manusia (HAM) terutama bagi pekerja/buruh yang dirugikan oleh perusahaan yang melakukan PHK dan perlindungan itu diberikan kepada pekerja/buruh agar dapat menikmati semua hak-hak yang diberikan oleh hukum. Perlindungan hukum dalam pemutusan hubungan kerja yang terpenting adalah menyangkut kebenaran status pekerja dalam hubungan kerja serta kebenaran alasan PHK. Alasan yang dipakai dasar untuk menjatuhkan PHK yang dapat dibagi dalam dua kelompok, yaitu alasan yang diizinkan dan alasan yang tidak diizinkan untuk di-PHK. Bentuk perlindungan hukum yang dapat diberikan kepada pekerja/buruh adalah dengan adanya peraturan perundang-undangan seperti Undang-Undang Nomor 2 Tahun 2004 tentang Penyelesaian Perselisihan Hubungan Industrial, Undang-Undang Nomor 13 Tahun 2003 tentang Ketenagakerjaan, Undang-Undang Nomor 21 Tahun 2000 tentang Serikat Pekerja/Serikat

\footnotetext{
${ }^{16}$ Ibid, hal. 30.

${ }^{17}$ Adrian Sutedi, Hukum Perburuhan, (Jakarta: Sinar Grafika, 2009), hal. 37.
} 
Buruh, dan sebagainya yang mengatur mengenai pemenuhan hak-hak normatif bagi pekerja yang mengalami PHK. Pengusaha diwajibkan membayar uang pesangon, uang penghargaan masa kerja dan uang penggantian hak. Undang-Undang No 13 Tahun 2003 tentang Ketenagakerjaan Pasal 156 mengatur ketentuan dari kompensasi uang pesangon bagi pekerja yang terkena PHK. Jika terjadi pemutusan hubungan kerja, pengusaha diwajibkan membayar uang pesangon dan atau uang penghargaan masa kerja dan uang penggantian hak yang seharusnya diterima sesuai dengan ketentuan undang-undang.

1. Perhitungan uang pesangon tersebut sebagai berikut:

a. Masa kerja kurang dari satu tahun, berhak mendapatkan satu bulan upah.

b. Masa kerja satu tahun atau lebih tetapi kurang dari dua tahun, berhak mendapatkan dua bulan upah.

c. Masa kerja dua tahun atau lebih tetapi kurang dari tiga tahun, berhak mendapatkan tiga bulan upah.

d. Masa kerja tiga tahun atau lebih tetapi kurang dari empat tahun, berhak mendapatkan empat bulan upah.

e. Masa kerja empat tahun atau lebih tetapi kurang dari lima tahun, berhak mendapatkan lima bulan upah.

f. Masa kerja lima tahun atau lebih tetapi kurang dari enam tahun, berhak mendapatkan enam bulan upah.

g. Masa kerja enam tahun atau lebih tetapi kurang dari tujuh tahun, berhak mendapatkan tujuh bulan upah.

h. Masa kerja tujuh tahun atau lebih tetapi kurang dari delapan tahun, berhak mendapatkan delapan bulan upah.

i. Masa kerja delapan tahun atau lebih berhak mendapatkan sembilan bulan upah. 
2. Perhitungan untuk uang penghargaan masa kerja diatur dalam Pasal 156 ayat (3) sebagai berikut:

a. Masa kerja tiga tahun atau lebih tetapi kurang dari enam tahun, berhak mendapatkan dua bulan upah.

b. Masa kerja enam tahun atau lebih tetapi kurang dari sembilan tahun berhak mendapatkan tiga bulan upah.

c. Masa kerja sembilan tahun atau lebih tetapi kurang dari 12 tahun berhak mendapatkan empat bulan upah.

d. Masa kerja 12 tahun atau lebih tetapi kurang dari 15 tahun berhak mendapatkan lima bulan upah.

e. Masa kerja 15 tahun atau lebih tetapi kurang dari 18 tahun berhak mendapatkan enam bulan upah.

f. Masa kerja 18 tahun atau lebih tetapi kurang dari 21 tahun berhak mendapatkan tujuh bulan upah.

g. Masa kerja 21 tahun atau lebih tetapi kurang dari dua puluh empat tahun berhak mendapatkan delapan bulan upah.

h. Masa kerja 24 tahun atau lebih berhak mendapatkan 10 bulan upah.

3. Uang penggantian hak yang seharusnya diterima sebagai berikut:

a. Cuti tahunan yang belum diambil dan belum gugur.

b. Biaya atau ongkos pulang untuk pekerja/buruh dan keluarganya ke tempat pekerja/buruh diterima berkerja.

c. Penggantian perumahan, pengobatan dan perawatan ditetapkan $15 \%$ dari uang pesangon dan/atau uang penghargaan masa kerja bagi yang memenuhi syarat.

d. Hal-hal lain yang ditetapkan dalam perjanjian kerja, peraturan perusahan, atau perjanjian kerja bersama, misalnya uang pisah.

Dalam penyelesaian sengketa perburuhan, Undang-Undang Nomor 2 Tahun 2004 tentang Penyelesaian Perselisihan Hubungan Industrial, 
mensyaratkan bahwa penyelesaian secara non litigasi merupakan suatu keharusan yang wajib ditempuh terlebih dahulu oleh para pihak. ${ }^{18}$ Apabila penyelesaian secara non litigasi gagal dilaksanakan, maka perkara tersebut dapat dilakukan melalui Pengadilan Hubungan Industrial atau melalui jalur litigasi. Bentuk upaya hukum baik non litigasi dan litigasi juga merupakan bentuk perlindungan hukum bagi pekerja/buruh.

Berdasarkan kasus pemutusan hubungan kerja akibat adanya demosi pada pekerja PT Johnson Home Hygiene Products, Putusan Pengadilan Hubungan Industrial Nomor 238/PHI.G/2013/PN.JKT.PST serta Putusan Mahkamah Agung No. 566K/Pdt.Sus-PHI/2014, sudah merupakan bentuk perlindungan hukum bagi kedua belah pihak, terutama pada Putusan Mahkamah Agung No. 566K/Pdt.Sus-PHI/2014 yang kemudian juga menambahkan upah skorsing bagi pekerja. Dalam Putusan Mahkamah Agung No. 566K/Pdt.Sus-PHI/2014 tercantum bahwa pekerja/buruh berhak atas hak-hak normatif seperti kompensasi pesangon 2 (dua) kali Pasal 156 Ayat 2, uang penghargaan masa kerja 4 (empat) kali Pasal 156 Ayat 3, uang penggantian hak sesuai Pasal 156 Ayat 4 UU Ketenagakerjaan dengan total sebesar Rp. 608.490.300,-, serta kekurangan upah skorsing sebesar Rp. 24.051.000,-. Ketentuan mengenai pemberian uang pesangon bagi pekerja/buruh yang mengalami PHK tersebut mengacu pada Pasal 164 Ayat 3 dengan alasan efisiensi yaitu sebesar 2 (dua) kali ketentuan Pasal 156 Ayat 2 yang sebenarnya diketahui bahwa tindakan PHK oleh perusahaan dengan alasan efisiensi sendiri tidak dapat dibuktikan dengan adanya laporan keuangan 2 (dua) tahun terakhir yang telah diaudit oleh akuntan publik. Sehingga jika diteliti, maka pekerja seharusnya dapat menerima uang pesangon lebih dari sekedar ketentuan 2 (dua) kali Pasal 156 ayat 4. Namun

\footnotetext{
${ }^{18}$ Syahrul Machmud, Hukum Acara Khusus Pada Pengadilan Hubungan Industrial, (Yogyakarta: Graha Ilmu, 2014), hal. 71.
} 
disini dapat pula kita lihat bahwa hakim tidak sepenuhnya mengacu pada ketentuan hak normatif berdasarkan alasan efisiensi, dimana pekerja pada akhirnya menerima uang penghargaan masa kerja sebanyak 4 (empat) kali Pasal 156 ayat 3. Dengan demikian putusan hakim sesuai dengan Pasal 178 HIR dan 189 Rbg. adalah, upaya hakim menyelesaikan suatu sengketa perdata yang diajukan kepadanya, setelah melalui proses pembuktian, dan akhirnya hakim memperoleh keyakinan dalam putusannya yang diucapkan dalam persidangan untuk umum. ${ }^{19}$

Jadi, perlindungan hukum yang diterima pekerja Zairianti terpenuhi dengan adanya Putusan Mahkamah Agung No. 566K/Pdt.Sus-PHI/2014. Dengan adanya putusan tersebut, hakim memutus terjadinya pemutusan hubungan kerja antara kedua pihak serta pekerja Zairianti menerima uang pesangon, uang penghargaan masa kerja, uang penggantian hak serta upah skorsing yang selayaknya diterima.

\section{Penutup}

\section{A. Kesimpulan}

Berdasarkan uraian analisis yang telah dikemukakan, maka dapat disimpulkan bahwa demosi terjadi pada pekerja/buruh di PT Johnson Home Hygiene tidak sah karena tidak memenuhi syarat-syarat untuk dilakukannya demosi. Pertama, demosi yang dilakukan bukan karena adanya kesalahan atau pelanggaran yang dilakukan oleh pekerja/buruh melainkan karena alasan restrukturisasi departemen yang merupakan bentuk dari efisiensi, namun perusahaan tidak dapat membuktikan alasan efisiensi tersebut. Hal ini menunjukkan demosi yang dilakukan terkesan bentuk akal-akalan dari perusahaan untuk mem-PHK pekerjanya (faktor like or dislike). Kedua, penolakan PHK karena adanya alasan efisiensi tidak dapat dijadikan alasan

\footnotetext{
${ }^{19}$ Ibid, hal. 204.
} 
bagi perusahaan untuk mendemosikan pekerjanya. Terlebih alasan PHK karena adanya efisiensi juga harus memenuhi ketentuan Pasal 164 ayat 2 Undang-Undang Nomor 13 Tahun 2013 tentang Ketenagakerjaan. Jika memang perusahaan ingin memberikan jabatan baru kepada pekerja, seharusnya jabatan baru yang diterima oleh pekerja minimal jabatan yang setingkat atau selevel dengan jabatan sebelumnya. Hal ini terkait dengan kompetensi dan keahlian pekerja yang sejak awal bekerja sudah disepakati oleh kedua belah pihak baik perusahaan maupun pekerja. Ketiga, demosi tidak diatur secara khusus dalam Peraturan Perusahaan, Perjanjian Kerja, atau Perjanjian Kerja Bersama. Sehingga dapat dikatakan bahwa demosi yang terjadi pada pekerja di PT Johnson Home Hygiene Products merupakan demosi yang tidak sah karena merupakan demosi yang tidak beralasan dan bersifat inkonstitusional.

Bentuk perlindungan hukum yang diberikan terhadap pekerja/buruh sudah terpenuhi dengan diberikannya hak-hak normatif seperti uang pesangon, uang penghargaan masa kerja, dan uang penggantian hak melalui Putusan Mahkamah Agung Nomor 566 K.Pdt.Sus-PHI/2014. Namun apabila melihat alasan terjadinya PHK yang sebenarnya bukan karena alasan efisiensi melainkan PHK yang dilakukan sepihak oleh perusahaan tanpa alasan yang jelas, maka pekerja dapat menerima uang kompensasi yang lebih besar. Terlebih pekerja tidak melakukan suatu kesalahan atau pelanggaran apapun. Namun Putusan Mahkamah Agung Nomor 566 K.Pdt.Sus-PHI/2014 sudah diputus berdasarkan pertimbangan hakim yang seadil-adilnya sehingga menyelesaikan masalah yang ada.

\section{B. Saran}

Bagi pihak pengusaha atau perusahaan, agar mengusahakan tidak terjadinya PHK dengan mempertimbangkan alasan-alasan dilakukannya PHK terhadap pekerja/buruh. Alasan-alasan yang digunakan untuk mem- 
PHK pekerja harus dapat dibuktikan dan tidak serta merta mendemosikan pekerja yang menolak untuk di PHK dengan alasan yang tidak jelas. Begitu sebaliknya bagi pekerja yang menolak untuk di demosi juga tidak dapat dijadikan alasan bagi pihak pengusaha untuk kemudian mem-PHK pekerjanya, terlebih jika tidak tercapai kesepakatan antara kedua belah pihak. Mengenai demosi juga harus diberikan pengaturan secara jelas yang tercantum dalam Peraturan Perusahaan, Perjanjian Kerja, serta Perjanjian Kerja Bersama agar memiliki prosedur yang jelas dan dasar hukum yang mengikat.

Bagi pekerja/buruh, agar mengetahui dengan baik Peraturan Perusahaan, Perjanjian Kerja, dan Perjanjian Kerja Bersama yang berlaku dalam perusahaan serta berbagai peraturan perundang-undangan terkait dengan bidang ketenagakerjaan. Dengan tujuan apabila terjadi suatu sengketa atau perselisihan dalam hubungan kerja khususnya pemutusan hubungan kerja berkaitan dengan demosi, pekerja dapat mengetahui dengan baik masing-masing hak dan kewajiban pengusaha maupun pekerja.

\section{DAFTAR PUSTAKA}

\section{A. Buku-Buku}

Asikin, Zainal dkk. Dasar-Dasar Hukum Perburuhan. (Jakarta: Raja Grafindo Persada, 2008).

Asyhadie, Zaeni. Hukum Kerja, Hukum Ketenagakerjaan Bidang Hubungan Kerja. (Jakarta: Raja Grafindo Persada, 2007).

Asyhadie, Zaeni. Peradilan Hubungan Industrial. (Jakarta: Rajawali Pers, 2009).

Budiono, Abdul Rachmad. Hukum Perburuhan di Indonesia. Cetakan ke-3. (Jakarta: Raja Grafindo Persada, 1999).

Djumialdji, F.X. Perjanjian Kerja Edisi Revisi. Cetakan ke-4. (Jakarta: Sinar Grafika, 2010). 
Fajar, Mukti dan Yulianto Achmad. Dualisme Penelitian Hukum Normatif dan Empiris. Cetakan ke-1. (Yogyakarta: Pustaka Pelajar, 2010).

Gultom, Sri Subiandini. Aspek Hukum Hubungan Industrial. (Jakarta: Hecca Mitra Utama,2005).

Gultom, Sri Subiandini dan Ridwan Halim. Sari Hukum Perburuhan Aktual. Cetakan 1. (Jakarta: Djambatan, 1984).

Hadjon, Philipus M.. Perlindungan Hukum Bagi Rakyat Indonesia. (Surabaya: Peradaban, 2007).

Hariandja, Marihot Tua Effendi. Manajemen Sumber Daya Manusia, Pengadaan, Pengembangan, Pengkompensasian dan Pengikatan Produktivitas Karyawan. (Jakarta: Gramedia, 2002).

Husni, Lalu. Pengantar Hukum Ketenagakerjaan Indonesia. (Jakarta: PT Raja Grafindo Persada, 2000).

Hasibuan, Malayu S.P. Manajemen Sumber Daya Manusia. (Jakarta: PT Bumi Aksara, 2002).

Machmud, Syahrul. Hukum Acara Khusus Pada Pengadilan Hubungan Industrial. (Yogyakarta: Graha Ilmu, 2014).

Mangkunegara, A.A. Anwar Prabu. Manajemen Sumber Daya Manusia Perusahaan. (Bandung: Remaja Rosdakarya, 2002).

Manulang, Sendjun H. Pokok-Pokok Hukum Ketenagakerjaan Indonesia, Cetakan ke-2. (Jakarta: Rineka Cipta, 1995).

Manullang, M. dan Marihot Amh Manullang. Manajemen Personalia. (Yogyakarta: Gadjah Mada University Press, 2011).

Marzuki, Peter Mahmud. Penelitian Hukum. Edisi Revisi. (Jakarta: Kencana, 2005).

Mulyadi, Lilik. Kompilasi Hukum Pidana Dalam Perspektif Teoritik dan Praktik Peradilan. (Bandung: Mandar Maju, 2007).

Munandar, Ashar Sunyoto. Psikologi Industri dan Organisasi. (Jakarta: UIPress, 2001). 
Raharjo, Satjipto. Ilmu Hukum. (Bandung: Citra Aditya Bakti, 2000).

Rusli, Hardijan. Hukum Ketenagakerjaan 2003. Cetakan ke-1. (Jakarta: Ghalia Indonesia, 2004).

Siagian, Sondang P. Manajemen Sumber Daya Manusia. Cetakan ke-2. (Jakarta: Bumi Aksara, 1993).

Soedarjadi. Hukum Ketenagakerjaan di Indonesia. (Yogyakarta: Pustaka Yustisia, 2008).

Soepomo, Imam. Hukum Perburuhan Bidang Pelaksanaan Hubungan Kerja. Cetakan ke-5. (Jakarta: Djambatan, 1983).

Soepomo. Imam. Hukum Perburuhan Bidang Hubungan Kerja. Cetakan ke8. (Jakarta: Djambatan, 1994).

Subekti. Hukum Perdata. (Bandung: Intermasa, 2003).

Suratman. Manajemen Sumber Daya Manusia. (Jakarta: Raja Grafindo, 2006).

Sutedi, Adrian. Hukum Perburuhan. (Jakarta: Sinar Grafika, 2009).

Uwiyono, Aloysius dkk. Asas-Asas Hukum Perburuhan. Cetakan ke-2. (Jakarta: Rajawali Pers, 2014).

\section{B. Peraturan Perundang-Undangan}

Indonesia. Undang-Undang Dasar Negara Republik Indonesia Tahun 1945. . Kitab Undang-Undang Hukum Perdata. - Undang-Undang Nomor 21 Tahun 2000 tentang Serikat Pekerja/Serikat Buruh (Lembaran Negara Republik Indonesia Tahun 2000 Nomor 131, Tambahan Lembaran Negara Republik Indonesia Nomor 3989).

Undang-Undang Nomor 13 Tahun 2003 tentang

Ketenagakerjaan (Lembaran Negara Republik Indonesia Tahun 2003

Nomor 39, Tambahan Lembaran Negara Republik Indonesia Nomor 4279). 
. Undang-Undang Nomor 2 Tahun 2004 tentang Penyelesaian

Perselisihan Hubungan Industrial (Lembaran Negara Republik

Indonesia Tahun 2004 Nomor 6, Tambahan Lembaran Negara Republik Indonesia Nomor 4356).

. Peraturan Menteri Tenaga Kerja dan Transmigrasi Nomor 31

Tahun 2008 tentang Pedoman Penyelesaian Perselisihan Hubungan

Industrial Melalui Perundingan Bipartit.

- Keputusan Menteri Tenaga Kerja Nomor 150 Tahun 2000

tentang Penyelesaian Pemutusan Hubungan Kerja dan Penetapan

Uang Pesangon, Penghargaan Masa Kerja dan Ganti Kerugian di

Perusahaan.

\section{Putusan Pengadilan}

Indonesia. Putusan Pengadilan Hubungan Industrial Nomor: 238 /PHI.G/2013/PN.JKT.PST.

. Putusan Mahkamah Agung Republik Indonesia Nomor: 566 K/Pdt.Sus-PHI/2014.

\section{Jurnal}

A.L, Noor Aini Pratitha dan Yasmin Chairunisa Muchtar, "Pengaruh

Penerapan Promosi Dan Demosi Terhadap Prestasi Kerja Karyawan

Pada Master Kredit Cabang Medan”. Jurnal USU. Volume 1, Nomor

1 Tahun 2013.

Husna, Dinal dkk. "Prestasi Kerja, Kondisi Organisasi, Perilaku Disfungsional dan Demosi Pns.” Jurnal Kebijakan Publik. Volume 3, Nomor 2 Tahun 2012.

\section{E. Kamus}

Poerwadarminta, W.J.S. Kamus Umum Bahasa Indonesia. Cetakan ke-10. (Jakarta: Balai Pustaka, 1987).

\section{F. Wawancara}


Damanik, Sehat. Wawancara dengan penulis. Fakultas Hukum Universitas Tarumanagara, 18 April 2018.

Sinambela, J. Erikson. Wawancara dengan penulis. Kementerian Tenaga Kerja Republik Indonesia, 9 April 2018.

Yurikosari, Andari. Wawancara dengan penulis. Fakultas Hukum Universitas Tarumanagara, 2 Mei 2018. 